\title{
ENKELE NUWE PUBLIKASIES
}

Tijdschrift voor. Nederlands en Afrikaans

T.N.A. word van Maart 1983 af uitgegee deur die Instituut vir Nederlandse Filologie aan die Universiteit van Keulen. In dic redaksionele inleiding tot die eerste nommer word die oogmerke van die tydskrf soos volg uitcengesit: "Nederlands en Afrikaans zijn hier (Keulen) vreemde talen, exponenten van vreemde culturen. Daaruit is de gedachte ontstaan om een orgaan op te richten, dat de kennis van de Nederlandse en Afrikaanse taal en cultuur in het buitenland wil bevorderen. Daarom zullen Engelstalige en Duitstalige bijdragen sterk vertegenwoordigd zijn, zonder evenwel Nederlands en Afrikaans verdringen." Wat Afrikaans betref, verskyn in die eerste uitgawe 'n bydrae oor "Die dans van die reën" (Marais) en "Afrikaanse leenvertalings uit Frans".

Redaksieadres: Institut für Niederländische Philologie der Universität zu Köln

Lindenthalgürtel $15 \mathrm{a}$

$5000 \mathrm{Köln} 41$

Bundesrepublik Deutschland.

'T.N.A. verskyn dric maal per jaar en beoog ongeveer 350 bladsye per jaargang. Die intekengeld beloop DM 38 per jaargang en DM 15 per los nommer, posgeld ingesluit.

Adres vir bestelling: Franz.J. Lukassen Verlag

Wiener Weg 3b

5000 Köln

Bundesrepublik Deutschland.

Texte: revue de critique et de thénrie littéraire

The Editors (B.'T. Fitch and Andrew Oliver, Trinity College, University of Toronto, 'Toronto (anada M5S 1H8) announce the creation of the new scholarly journal, Texte, appearing annually. 'The journal has chosen as its focus the exploration of the different meanings of the tcrm in its title and the different critical perspectives which have been brought to bear on it. The first issue (Fall/Winter 1982) deals with 'L'Autoreprésentation - le texte et ses miroirs'; manuscripts should be in French or English. Texte is also part of a larger scholarly publishing enterprise. Using the resources of modern technology, it is the intention of the publishers to make available to the scholarly community research materials which would otherwise be un- 
publishable or, at least, publishable only with great difficulty given the high cost of traditional publishing metods: critical editions, research bibliographies, translations of signilicant scholarly work as yet unavailable in English or French, these are the types of material which they hope to publish. Readers who have material or know of material which might be ol interest are invited to write to the Editors.

Bibliografie an Louis Ciouperus

A.M. Bisscholf

Bibliografie van Lou is Couperus

Wetenskaplike Bydraes van die PU vir CHO

Reeks A: Geesteswetenskappe, nr. 43

95 pp.

Prys: R1,50

Die bibliogralie bestaan uit vyf kategorieë:

1. Werke deur Louis Couperus

Verdere navorsingsmateriaal aangaande Couperus se werk:

2. Monografieë, versamelbundels en ensiklopedieë

3. Tydskrifte

4. Bibliogralieë oor Couperus

5. Werke waarin Couperus vermeld word maar sy werke nie eksplisiet betrek word nie.

Adres vir navrae:

Die Hoof

Sentrale Publikasie-departement

Potchefstroomse Universiteit vir CHO

2520 Potchelstroom Suid-Afrika 